\title{
Polish adaptation and validation of the Dieting Self-Efficacy Scale
}

\begin{abstract}
BACKGROUND
Dieting self-efficacy is defined as individual's belief in his or her ability to adhere to a diet in order to lose or maintain current weight. Self-efficacious individuals can overcome challenges and obstacles while dieting. The main objective of this study is to report the psychometric properties of the first Polish adaptation of the Dieting Self-Efficacy Scale (DIET-SE) of Christine Stich, Barbel Knauper, and Ami Tint. The original Canadian DIET-SE is a scenario-based scale assessing dieting self-efficacy for weight loss and maintenance. It consists of three subscales and assesses dieting self-efficacy for three different types of temptation situations.
\end{abstract}

PARTICIPANTS AND PROCEDURE

There were 552 students (age $M=20.32, S D=2.98$ ) participating in the study. The original Canadian Dieting Self-Ef- ficacy Scale was translated into Polish, and its factor structure, reliability and construct validity were determined.

\section{RESULTS}

The study showed that the Polish version of the Dieting Self-Efficacy Scale is a reliable and valid scale. The obtained results support the same three-factor structure that was previously documented in the original version of the scale.

\section{CONCLUSION}

The Polish version of the DIET-SE can be used to identify personal factors that obstruct weight reduction or weight maintenance.

KEY WORDS

dieting self-efficacy; obesity; weight reduction; weight maintenance

ORGANizATION - University of Warmia and Mazury, Department of Psychology of Development and Education, Olsztyn,

Poland

AUthors' CONTRibutions - A: Study design - B: Data collection - C: Statistical analysis - D: Data interpretation .

E: Manuscript preparation · F: Literature search · G: Funds collection

CORRESPONDING AUTHOR - Malgorzata Obara-Gołębiowska, Department of Psychology of Development and Education,

University of Warmia and Mazury, 13 Prawocheńskiego Str., 10-725 Olsztyn, Poland,

e-mail: malgorzata.obara@gmail.com

to Cite this ARTICLE - Obara-Gołębiowska, M., \& Michałek-Kwiecień, J. (2018). Polish adaptation and validation of the

Dieting Self-Efficacy Scale. Health Psychology Report, 6(2), 183-191. doi: https://doi.org/10.5114/hpr.2018.72044

RECEIVED 04.01.2017 · REVIEWED 26.01.2017 · ACCEPTED 29.04.2017 · PUBLISHED 07.12.2017 


\section{BACKGROUND}

Weight loss requires a change in eating habits. In most cases, people who have successfully lost weight regain it after some time. For this reason, obesity-related research programs increasingly often focus on psychological and behavioral factors that make lifestyle changes and weight reduction maintenance efficacious.

According to the literature, self-efficacy plays
Małgorzata

Obara-

Gołębiowska, Justyna MichałekKwiecień a mediating role in behavior change in many areas such as alcohol abstinence (Kuerbis, Armeli, \& Muench, 2013), smoking cessation (Li et al., 2015), increasing exercise (Heijden, Pouwer, \& Pop, 2014), diabetes self-care management (Rak, 2014) or weight loss and weight maintenance (Armitage, Parfitt, Pegington, Donnelly, \& Harvie, 2014, Choo \& Kang, 2015). Dieting self-efficacy is defined as an individual's belief in his or her ability to adhere to a diet in order to lose or maintain current weight (Stotland \& Zuroff, 1991). Studies dedicated to self-efficacy's impact on the weight reduction process support that self-efficacious individuals believe that they can overcome challenges and obstacles while dieting (Rodin, Elias, Silberstein, \& Wagner, 1988; Armitage et al., 2014). Therefore they show more effort and stronger persistence in adhering to their slimming related goals (Latner, Mc Leod, O’Brien, \& Johnston, 2013). Those people also present better coping strategies because of initiation of behavioral change and learning from their experience how to better manage difficult situations (Rodin et al., 1988; Armitage et al., 2014). Furthermore, after breaking their diets self-efficacious individuals recover more quickly and better adhere to their previous goals (Rodin et al., 1988; Armitage et al., 2014). The Self-Efficacy Scale in Weight Reduction (SES-WR) by Ogińska-Bulik and Putyński (Ogińska-Bulik, 2004) is an effective tool used by Polish researchers. The overall score reflects the subject's perceived sense of self-efficacy in reducing and maintaining weight. The General Self-Efficacy Scale (GSES) developed by Schwarzer, Jerusalem and Juczyński (2009) can also be used to measure the sense of self-efficacy, including subjects undergoing a weight loss program. However, the GSES was designed to assess self-beliefs regarding the general ability to cope with difficult situations. A tool that supports more accurate evaluations of dieting self-efficacy is the Diet Self-Efficacy Scale (DIET-SE), a scenario-based measure proposed by Stich, Knauper and Tint (2009). An advantage of the DIET-SE is that unlike the previously mentioned Polish tools, the DIET-SE consists of three subscales, and it assesses self-efficacy for three different types of exposure to tempting situations. Those types of situations in which an individual particularly lacks self-efficacy can be covered by the weight loss program. Psychological diagnosis using the DIET-SE and therapy related to develop- ment of dieting self-efficacy skills might result in better weight loss and maintenance success.

The goal of the study was to assess the factor structure, reliability and construct validity of the DIET-SE.

\section{PARTICIPANTS AND PROCEDURE}

\section{PARTICIPANTS}

The study was conducted with undergraduate students of the Faculty of Social Sciences of the University of Warmia and Mazury in Olsztyn. All participants gave written consent to participate and the study was approved by the Bioethics Committee of the University of Warmia and Mazury, Olsztyn, Poland. Questionnaires properly filled out by 552 students [451 (81.00\%) females and 101 (18.30\%) males] were subjected to statistical analysis. Mean age of participants was $20.32(S D=2.98)$ and mean BMI (body mass index) was $21.91(S D=2.67)$.

\section{MEASURES}

\section{The Dieting Self-Efficacy Scale}

The DIET-SE consists of 11 items (Stich et al., 2009). It asks respondents to indicate their confidence in their ability to resist a variety of eating temptations. Responses are assessed on a Likert-type scale rating from 0 to 4 . Test-retest correlations of DIET-SE were $r=.83$. Exploratory and confirmatory factor analyses revealed that the DIET-SE contains three subscales. The first subscale, HCF (high-caloric food), describes situations of the exposure to high-caloric food as an obstacle in dieting. The second, SIF (Social and Internal factors), presents situations in which social (e.g. dinner with family) or internal factors (e.g. being tired) can also make it difficult to resist food temptation. The third subscale (negative emotional events NEE) shows examples where emotional discomfort can be the cause of unplanned eating. Internal consistency analyses demonstrated high internal consistency for the overall scale (11 items) $(\alpha=.82)$ and for separate subscales [HCF (4 items), $\alpha=.70$; SIF (4 items), $\alpha=.71$ and NEE (3 items), $\alpha=.75$ ].

\section{THE PROCEDURE OF TRANSLATING THE DIET-SE}

The scale was translated from English into Polish by three persons acting independently: a sworn translator of English and two psychologists who were holders of Cambridge Certificates of Proficiency in English. Their translations were compared and analyzed to develop a single Polish version of the scale. The scale was then translated from Polish into English by 
three persons acting independently: one physician and two psychologists who were fluent in English. No significant differences were reported.

\section{TOOLS USED TO CONSTRUCT VALIDITY ASSESSMENT IN POLISH ADAPTATION OF DIET-SE}

\section{The Self-Efficacy Scale in Weight Reduction by Ogińska-Bulik and Putyński (Ogińska-Bulik, 2004)}

The SES-WR was selected for this study because it is the only Polish-language research tool which is suited for evaluations of self-efficacy associated particularly with weight reduction. The higher the general result, the weaker the perceived sense of self-efficacy and persistence in the weight loss process. For construct validity, it was hypothesized that SES-WR and DIET-SE would be negatively correlated with regard to the overall DIET-SE and its three subscales.

The General Self-Efficacy Scale (GSES) by Schwarzer, ferusalem and Fuczyński (Fuczyński, 2009)

The scale was created to assess the respondent's sense of perceived self-efficacy in coping with daily problems. In the literature, adherence to goals is positively correlated with general self-efficacy levels (Niazi, Adil, \& Malik, 2013). In the present study, we expected that general self-efficacy measured by GSES would be positively correlated with the overall DIET-SE and each of its subscales.

\section{The Eating Behaviors Subscale (EBS) of the Health Behaviors Inventory (HBI) by fuczyński (2009)}

The Health Behaviors Inventory assesses four aspects of health behaviors: eating habits, health prevention, positive attitude and health practices. The higher the score in the entire inventory or its particular aspects, the healthier the respondent's behaviors. DIET-SE was adapted using the Eating Behaviors Subscale of the HBI, and positive correlations were expected between the two. Based on the information found in the literature, we assumed that self-efficacy in diet adherence should be accompanied by healthier eating behaviors (Armitage et al., 2014).

\section{Body mass index (BMI) assessment}

Since higher dieting self-efficacy has been shown to positively affect successful dieting behavior, it was predicted that the DIET-SE would positively correlate with diet adherence (Wiltink, 2007). Therefore the BMI, which can be used as a measure of successful weight maintenance, was used as an additional construct validity criterion. It was also applied in original DIET-SE validation. BMI was calculated using self-reported height and weight. Similarly to the original DIET-SE validation process, we expected negative correlations between BMI and overall DIET-SE or its three subscales.

\section{RESULTS}

\section{STATISTICAL ANALYSIS}

The basic statistical analyses were performed with the software package SPSS $21 \mathrm{PL}$, and we used the SEPATH program of the STATISTICA software version 10 PL to conduct confirmatory factor analysis.

\section{RELIABILITY}

The Cronbach's $\alpha$ coefficient for the DIET-SE scale was $.79(M=24.72, S D=7.90)$, whereas for the three subscales the internal consistency values ranged from .69 to .73 , which is considered as acceptable internal consistency depending on the generality-specificity of the construct when the number of items is small (e.g. 5 or less, like in DIET-SE subscales) (Clark \& Watson, 1995). In the original research $\alpha$ values ranged from .70 to .87 (Kuerbis, Armeli, \& Morgenstern, 2013; Stich et al., 2009). In addition, we used McDonald's omega $(\omega)$ to estimate the internal consistency of DIET-SE, as it is a better estimator of reliability than Cronbach's $\alpha$ (Graham, 2006; Sijtsma, 2009). The omega indicator showed only acceptable reliability, for the whole scale $\omega=.50$, HCF $\omega=.46$, SIF $\omega=.43$, NEE $\omega=.42$. The results show that the internal consistency of the DIET-SE, using both Cronbach's $\alpha$ and McDonald's omega, in the current study is sufficient.

In addition, the item-total correlations were calculated using Pearson's correlation coefficient between the individual item and the total scale as well as the subscale (which includes the item). In our study, .30 was taken as the lower limit for item-total correlations (Schumacker \& Lomax, 2010; Brown, 2006). The item-total reliability coefficients ranged between .46 and .80 (for most items this coefficient exceed .60; all correlations were statistically significant: $p<.001$ ).

Test-retest reliability was assessed on a separate group of 197 students with an interval of 4 months. The results confirmed the high test-retest reliability for the DIET-SE (total score: $r=.80$; HCF: $r=.76$; SIF: $r=.81$; NEE $-r=.81$ ), similarly as in the original study.

\section{CONSTRUCT VALIDITY - CONFIRMATORY FACTOR ANALYSIS}

While testing univariate normality, skewness kurtosis values were calculated for each item. Mostly uni-
The Dieting Self-Efficacy Scale 
Małgorzata

Obara-

Gołębiowska, Justyna MichałekKwiecień variate skewness and kurtosis values were approximately normal (range of -1 to +1 ) (Kline, 2011; Rak, 2014). Therefore, confirmatory factor analysis (CFA) with maximum likelihood estimation was used to test the factorial validity of the Polish version of the DIET-SE (Kline, 2011). Table 1 presents the fit indices of the three-factor model from the current study and from the original one (Stich et al., 2009). The model with two error correlations had acceptable fit indices.

The indices used to test model fit were root mean square error of approximation (RMSEA), chi-square $\left(\chi^{2}\right)$, comparative fit index $(\mathrm{CFI})$, and the BentlerBonett non-normed fit index (NNFI). RMSEA shows the level of fit of the model to the covariance matrix, taking into account the number of degrees of freedom and the sample size (Brown, 2006). The typical cut-off value for RMSEA is < .06, but it is generally reported in conjunction with the RMSEA, and in a well-fitting model the lower limit is close to 0 while the upper limit should be less than .08 (Hu \& Bentler, 1999; Marsh, Hau, \& Wen, 2004). Acceptable model fit is indicated by a CFI value of .90 or greater (Brown, 2006). NNFI with an acceptable level cut-off of close to .95 (Hu \& Bentler, 1999) in our study achieved the value of 91 .

Figure 1 shows the factor structure of the DIET-SE questionnaire. In our study four factor loadings obtained a satisfactory level above $.70(\mathrm{~d} 3, \mathrm{~d} 5, \mathrm{~d} 7, \mathrm{~d} 8)$. Other factors' loadings range from .44 to .68 , while still being located in the recommended cut-off assumption in the range of .40-.50 (Matsunaga, 2010). Indices of confirmatory factor analysis of DIET-SE, from current and original studiesare presented in Table 2.

Table 1

Intercorrelations of scales with DIET-SE and its subscales

\begin{tabular}{|c|c|c|c|c|c|c|c|c|c|}
\hline \multicolumn{2}{|c|}{ Scales } & \multicolumn{2}{|c|}{ Diet-Se } & \multicolumn{2}{|c|}{$\mathrm{HCF}$} & \multicolumn{2}{|c|}{ SIF } & \multicolumn{2}{|c|}{ NEE } \\
\hline & & $r$ & $p$ & $r$ & $p$ & $r$ & $p$ & $r$ & $p$ \\
\hline 1. & $\begin{array}{l}\text { HCF } \\
\text { (Diet-Se) }\end{array}$ & .79 & $<.001$ & & & & & & \\
\hline 2. & $\begin{array}{l}\text { SIF } \\
\text { (Diet-Se) }\end{array}$ & .77 & $<.001$ & .39 & $<.001$ & & & & \\
\hline 3. & $\begin{array}{l}\text { NEE } \\
\text { (Diet-Se) }\end{array}$ & .70 & $<.001$ & .34 & $<.001$ & .32 & $<.001$ & & \\
\hline 5. & GSES & .44 & $<.001$ & .38 & $<.001$ & .31 & $<.001$ & .29 & $<.001$ \\
\hline 6. & SES-WR & -.43 & $<.001$ & -.28 & $<.001$ & -.40 & $<.001$ & -.29 & $<.001$ \\
\hline 7. & $\mathrm{HBI}$ & .38 & $<.001$ & .21 & $<.001$ & .32 & $<.001$ & .35 & $<.001$ \\
\hline 8. & $\mathrm{~EB}(\mathrm{HBI})$ & .54 & $<.001$ & .43 & $<.001$ & .44 & $<.001$ & .34 & $<.001$ \\
\hline 9. & $\mathrm{BMI}$ & .02 & .647 & .01 & .839 & -.02 & .662 & .06 & .133 \\
\hline
\end{tabular}

Note. $r=$ correlation coefficient; $p=p$ value, DIET-SE $=$ Dieting Self-Efficacy Scale; HCF (DIET-SE) $=$ High-Caloric Food subscale of DIET-SE; SIF (DIET-SE) = Social and Internal Factors subscale of DIET-SE; NEE (DIET-SE) = Negative Emotional Events subscale of DIET-SE; GSES = General Self-Efficacy Scale; SES-WR = Self-Efficacy Scale in Weight Reduction; HBI = Health Behaviors Invento$r y ; \mathrm{EB}(\mathrm{HBI})=$ Eating Behaviors subscale of $\mathrm{HBI} ; \mathrm{BMI}=$ body mass index.

Table 2

Indices of confirmatory factor analysis of DIET-SE, from current and original studie

Three-factor model

$\chi^{2}(d f, N) \quad$ CFI $\quad$ RNFI $\quad$ RMSEA $(90 \% \mathrm{CI})$

\begin{tabular}{lllll}
\hline $\begin{array}{l}\text { Original study } \\
\text { Current study }\end{array}$ & $52.78(41,123)$ & .99 & .92 & .05 \\
$\begin{array}{l}\text { (three-factor model } \\
\text { with one error correla- }\end{array}$ & $134.31(39,552)$ & .94 & .91 & $.067(.054, .079)$
\end{tabular}

tion, without item d2)

Note. $\chi^{2}$ - chi-square; $d f$ - degrees of freedom; $N$ - sample size; CFI - comparative fit index; NNFI - Bentler-Bonett non-normed fit index; RMSEA - root mean square error of approximation; $\mathrm{Cl}$ - confidence interval. 


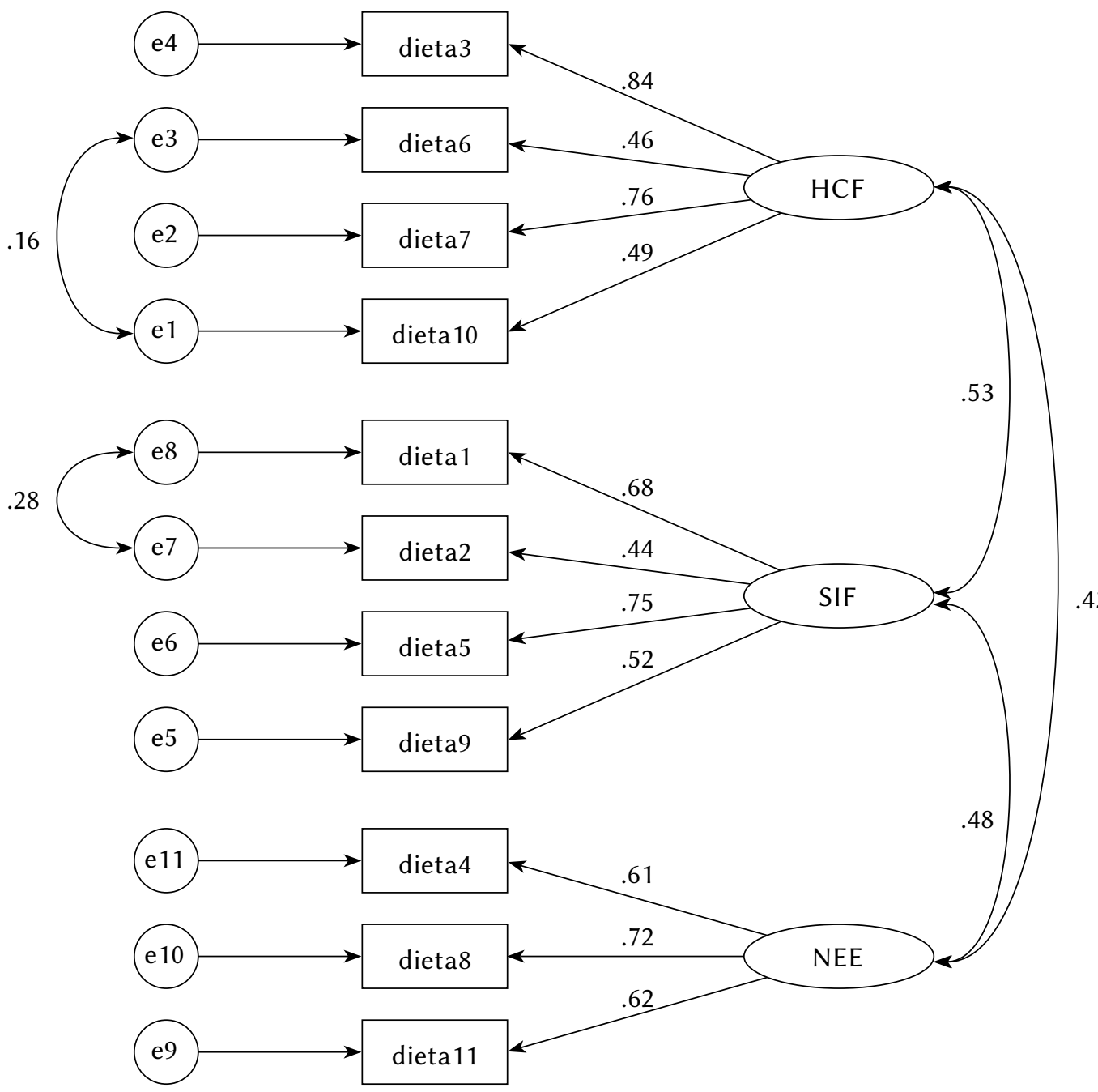

The Dieting Self-Efficacy Scale

Figure 1. Factorial structure of the DIET-SE.

\section{CRITERION VALIDITY}

In order to test criterion validity of the DIET-SE, associations between scores obtained from The Self-Efficacy Scale in Weight Reduction (SES-WR), the General Self-Efficacy Scale (GSES), the Eating Behaviors Subscale (EB) of the Health Behaviors Inventory $\mathrm{HBI}$ and body mass index (BMI) were examined. As can be seen in Table 1, in accordance with previous predictions, there were negative correlations between DIET-SE as well as its subscales and SES-WR ( $r$ ranged between -.43 and $-.28, p<.001)$. Also DIET-SE and its subscales positively correlated with GSES ( $r$ ranged between .44 and $.29, p=.010)$. Positive correlations were also obtained between DIET-SE as well as its subscales and the Eating Behaviors Subscale of the HBI ( $r$ ranged between .54 and $.34, p<.001$ ). However, the correlations between DIET-SE and BMI of surveyed subjects were found to be insignificant, which was in contrast with our initial expectations. Also the authors of the original DIET-SE, who expected negative correlations between DIET-SE and BMI, obtained mixed results. In one of their studies (study 1b) there were no correlations between DIET-SE and BMI, in contrast with their initial expectations, while in an other study (study 3) there were observed negative correlations as expected (Stich et al., 2009).

\section{DISCUSSION}

The objective of this study was to adapt the DIET-SE, the Canadian research tool developed by Stich et al. (2009), for the needs of Polish respondents. The DIET-SE assesses dieting self-efficacy for weight loss and maintenance. It consists of three subscales related to self-efficacy in diet adherence, and it extends the scope of the existing Polish tool, the SES-WR. The DIET-SE is a more accurate measure of perceived self-efficacy in dieting. It can play an important role in the conceptualization of problems relating to diet control, including in the treatment of obesity and eating disorders. It can also be applied in programs of health prevention concerning eating habits. The Polish and English versions of the scale are presented in Table 3. 
Table 3

Polish and English-language versions of DIET-SE

\begin{tabular}{ccc}
\hline Items & Skala Poczucia Wtasnej Skuteczności & Dieting Self-Efficacy Scale (DIET-SE) \\
w Przestrzeganiu Diety (SPWSPD) & \\
\hline & Jesz z rodziną obiad, na który przygotowano & You are having dinner with your family and \\
Twoje ulubione danie. Kiedy kończysz pierw- & $\begin{array}{c}\text { your favorite meal has been prepared. You } \\
\text { szą porcję, ktoś mówi: „Dlaczego nie doło- }\end{array}$ & $\begin{array}{c}\text { finish the first helping and someone says, "Why } \\
\text { don’t you have some more?” How confident }\end{array}$ \\
& $\begin{array}{c}\text { żysz sobie jeszcze trochę?” Jak bardzo jesteś } \\
\text { przekonana/przekonany, że podziękujesz za } \\
\text { dokładkę? }\end{array}$ & $\begin{array}{c}\text { are you that you would turn down a second } \\
\text { helping? }\end{array}$
\end{tabular}

Podczas kolacji często się przejadasz, ponieważ jesteś zmęczona/zmęczony i głodna/głod-

Gołębiowska, Justyna MichałekKwiecień

ny po powrocie do domu. Jak bardzo jesteś przekonana/przekonany, że nie zjesz za dużo na kolację?

You often overeat at supper because you are tired and hungry when you get home. How confident are you that you would not overeat at supper?

W pracy zorganizowano przyjęcie dla Twojego współpracownika. Ktoś proponuje Ci kawałek ciasta. Jak bardzo jesteś przekonana/przekonany, że podziękujesz i odmówisz?

Właśnie miałaś/miałeś przykrą sprzeczkę z członkiem rodziny. Stoisz przed otwartą lodówką i czujesz, że zjesz wszystko, co znajduje się w zasięgu Twojego wzroku. Jak bardzo jesteś przekonana/przekonany, że znajdziesz inny sposób poprawienia sobie samopoczucia?

Zostałaś/Zostałeś zaproszony na obiad, a gospodarz przyjęcia jest świetnym kucharzem. Często się przejadasz, ponieważ jedzenie tak wspaniale smakuje. Jak bardzo jesteś przekonana/przekonany, że nie przejesz się na tym obiedzie?

Skończyłaś/skończyłeś posiłek, ale nadal czujesz się głodna/głodny. Przed Tobą stoją ciasta i owoce. Jak bardzo jesteś przekonana/przekonany, że wybierzesz owoce?

Jesteś w domu przyjaciela, który proponuje $\mathrm{Ci}$ spróbowanie wspaniale wyglądającego ciasta. Jak bardzo jesteś przekonana/przekonany, że podziękujesz i odmówisz?

Masz ciężki dzień w pracy, jesteś zdenerwowana/zdenerwowany i zaniepokojona/zaniepokojony. Masz ochotę na batonik. Jak bardzo jesteś przekonana/przekonany, że znajdziesz bardziej konstruktywny sposób uspokojenia się i poradzenia sobie ze swoimi uczuciami?

Masz ochotę się rozerwać. Wychodzisz z przyjaciółmi do dobrej restauracji. Jak bardzo jesteś przekonana/przekonany, że potrafisz dobrze się bawić bez przejadania?

Wychodzisz z przyjaciółmi w porze lunchu i jeden z nich sugeruje kupno lodów. Jak bar-

There is a party at work for a coworker and someone offers you a piece of cake. How confident are you that you would turn it down?

You just had an upsetting argument with a family member. You are standing in front of the refrigerator and you feel like eating everything in sight. How confident are you that you would find some other way to make yourself feel better?

You are invited to someone's house for dinner and your host is an excellent cook. You often overeat because the food tastes so good. How confident are you that you would not overeat as a dinner guest?

You finished your meal and you still feel hungry. There are cakes and fruits available. How confident are you that you would choose the fruits?

You are at a friend's house and your friend offers you a delicious looking pastry. How confident are you that you would refuse this offer?

You are having a hard day at work and you are anxious and upset. You feel like getting a candy bar. How confident are you that you would find a more constructive way to calm down and cope with your feelings?

You feel like celebrating. You are going out with friends to a good restaurant. How confident are you that you would celebrate without overeating?

You are out with a friend at lunch time and your friend suggests that you stop and get some ice cream. How confident are you that you would resist the temptation?

(Table 3 continues) 
Table 3

(Table 3 continued)

\begin{tabular}{|c|c|c|}
\hline Items & $\begin{array}{c}\text { Skala Poczucia Wtasnej Skuteczności } \\
\text { w Przestrzeganiu Diety (SPWSPD) }\end{array}$ & Dieting Self-Efficacy Scale (DIET-SE) ${ }^{1}$ \\
\hline 11 & $\begin{array}{l}\text { Miałaś/miałeś właśnie sprzeczkę ze swoim } \\
\text { chłopakiem/dziewczyną. Jesteś zaniepokojo- } \\
\text { na/zaniepokojony i zła/zły i masz ochotę coś } \\
\text { zjeść. Jak bardzo jesteś przekonana/przekona- } \\
\text { ny, że zamiast sięgać po jedzenie, porozma- } \\
\text { wiasz o tym z kimś lub pójdziesz na spacer? }\end{array}$ & $\begin{array}{l}\text { You just had an argument with your boyfriend } \\
\text { or girlfriend. You are upset, angry, and you feel } \\
\text { like eating something. How confident are you } \\
\text { that you would talk the situation over with } \\
\text { someone or go for a walk instead of eating? }\end{array}$ \\
\hline
\end{tabular}

The Dieting Self-Efficacy Scale

The results of the validation process demonstrated sufficient internal consistency of the DIET-SE and significant item-total correlations. Similarly to the original study, the test-retest reliability for the DIET-SE was high (Stich et al., 2009). A confirmatory factor analysis (CFA) with maximum likelihood estimation confirmed the results reported by the authors of the DIET-SE. In the Polish version of the scale, three factors with sufficient loading levels were identified. Criterion validity for DIET-SE was established using the SES-WR, GSES, EBS (HBI) and BMI. In most cases, the correlations between the DIET-SE and the above scales were consistent with our initial expectations. Higher self-efficacy in weight reduction measured by the SES-WR was greater in subjects who scored higher in the DIET-SE scale and subscales. Students characterized by high general self-efficacy measured by GSES were also highly conscientious in adhering to their diets. It confirms that people with higher general self-efficacy are more persistent in modifying their eating habits (Matsuo, Murotake, \& Kim, 2010). The study also revealed that the quality of eating habits presented in the EBS (HBI) is related to self-efficacy in dieting. Similar observations were found in the literature (Nastaskin \& Fiocco, 2015). Similarly to the study validating the original DIET-SE, BMI was not correlated with DIET-SE. This could be attributed to the fact that body weight is influenced by numerous factors, including genetic, social and physical (Heitmann, Westerterp, \& Loos, 2012). For this reason, the impact of a single factor, such as dieting self-efficacy, on BMI may be very difficult to observe. However, there are some limitations to the present study that should inform future work. The first study was conducted on young people with the mean age of 20.32 years (2.98). Self-efficacy is influenced by experience, and it can be assumed that the participants' age was a modifying factor. For this reason, the Polish version of the DIET-SE should be additionally validated on a group of older respondents.

Similarly to the study verifying the original version of the scale, most subjects were female, which could also influence the results. Women are much more likely to focus on body image, in particular body weight, than men, and they also make more frequent attempts to change their eating habits (Glebocka \& Kulbat, 2005). Past dieting experiences could exert a significant influence, both positive and negative, on the sense of self-efficacy. In view of the above, future validation research covering male respondents would be an interesting follow-up of the present study.

\section{CONCLUSIONS}

The results of this study demonstrated that the Polish version of the DIET-SE is a reliable and valid scenario-based diagnostic tool which can be used to identify personal factors that obstruct weight reduction or weight maintenance.

Future research could determine whether the DIET-SE could improve the effectiveness of weight loss programs. One of the greatest advantages of the DIET-SE is that it measures dieting self-efficacy in three different situations. Follow-up studies could also evaluate the respondents' individual susceptibility on the three subscales of the DIET-SE (HCF, NEE, SIF) to verify the effectiveness of a personalized weight loss program. During personalized therapy, respondents would learn strategies that would enable them to resist the greatest temptations and cope with the most problematic situations. Individual coping strategies would assist patients in building positive experiences related to dietary adherence, and experience of success is the best way to improve self-efficacy (Schwarzer \& Renner, 2000).

\section{ACKNOWLEDGEMENTS}

The authors acknowledge the funding of this study provided by the University of Warmia and Mazury, Social Science Department, Prawochenskiego 13, Olsztyn, Poland.

\section{ENDNOTES}

1 Source: Stich, Knauper, \& Tint, 2009. 


\section{REFERENCES}

Armitage, C., Parfitt, G., Pegington, M., Donnelly, L., \& Harvie, M. N. (2014). Self-efficacy for temptations is a better predictor of weight loss than motivation and global self-efficacy: Evidence from two prospective studies among overweight/obese women at high risk of breast cancer. Patient Education and Counseling, 95, 254-258. doi: 10.1016/j.pec.2014.01.015

Brown, T. A. (2006). Confirmatory Factor Analysis for Applied Research. New York \& London: The Guilford Press.

Obara-

Gołębiowska, Justyna MichałekKwiecień

Choo, J., \& Kang, H. (2015). Predictors of initial weight loss among women with abdominal obesity: a path model using self-efficacy and health-promoting behaviour. Journal of Advanced Nursing, 7, 1087-1097. doi: 10.1111/jan.12604

Clark, L. A., \& Watson, D. (1995). Constructing validity: basic issues in objective scale development. Psychological Assessment, 7, 309-319. doi: 10.1037/1040-3590.7.3.309

Glebocka, A., \& Kulbat J. (2005). Ideal body images of female body shape in normal and pathological groups. Journal of Applied Psychology, 3, 88-98.

Graham, J. M. (2006). Congeneric and essentially tau-equivalent estimates of score reliability: What they are and how to use them. Psychological Assessment, 66, 930-944. doi: 10.1177/0013164406288165

Heijden, M., Pouwer, F., \& Pop, V. (2014). Psychometric Properties of the Exercise Self-efficacy Scale in Dutch Primary Care Patients with Type 2 Diabetes Mellitus. International Journal of Behavioral Medicine, 21, 394-401. doi: 10.1007/s12529-013-9308-z

Heitmann, B. L., Westerterp, K. R., Loos, R. J. F., Sorensen, T. I. A., O’Dea, K., McLean, P., ...Westerterp-Plantenga, M. S. (2012). Obesity: lessons from evolution and the environment. Obesity Reviews, 13, 910-922. doi: 10.1111/j.1467-789X.2012.01007.x

Hu, L., \& Bentler, P. M. (1999). Cutoff criteria for fit indexes in covariance structure analysis: Conventional criteria versus new alternatives. Structural Equation Modeling: A Multidisciplinary Journal, 6 , 1-55. doi: 10.1080/10705519909540118

Juczyński, Z. (2009). Narzędzia pomiaru w promocji i psychologii zdrowia [Instruments for measurements in health promotion and psychology]. Warszawa: Pracownia Testow Psychologicznych Polskiego Towarzystwa Psychologicznego.

Kline, R. B. (2011). Principles and practices of structural equation modeling (3rd ed.). New York, NY: Guilford Press.

Kuerbis, A., Armeli, S., \& Morgenstern, J. (2013). Motivation and self-efficacy in the context of moderated drinking: Global self-report and ecological momentary assessment. Psychology of Addictive Behaviors, 27, 934-943. doi: 10.1037/a0031194

Latner, J. D., Mc Leod, G., O’Brien, K. S., \& Johnston, L. (2013). The role of self-efficacy, coping, and lapses in weight maintenance. Eating and Weight Disorders: Studies on Anorexia, Bulimia and Obesity, 18, 359-366. doi: 10.1007/s40519-013-0068-1

Li, S., Fang, L., Zhou, Y., Pan, L., Yang, X., Li, H., ...Jia, C. (2015). Mediation of smoking abstinence self-efficacy on the association of nicotine dependence with smoking cessation. European Journal of Public Health, 25, 200-204. doi: 10.1093/eurpub/cku183

Marsh, H. W., Hau, K. T., \& Wen, Z. (2004). In search of golden rules: Comment on hypothesis testing approaches to setting cutoff values for fit indexes and dangers in overgeneralizing $\mathrm{Hu} \&$ Bentler's (1999) findings. Structural Equation Modeling: A Multidisciplinary Journal, 11, 320-341.

Matsunaga, M. (2010). How to Factor-Analyze Your Data Right: Do's, Don'ts, and How-To's. International Journal of Psychological Research, 3, 97-110.

Matsuo, T., Murotake, Y., Kim, M. J., Akiba, T., Shimojo, N., Kim, M. K., \& Tanaka, K. (2010). High general self-efficacy is associated with less weight loss under a supervised dietary modification program. Obesity Research \& Clinical Practice, 4, 83-162. doi: 10.1016/j.orcp.2009.12.00

Nastaskin, R. S., \& Fiocco, A. J. (2015). A survey of diet self-efficacy and food intake in students with high and low perceived stress. Nutritional Journal, 14, 1-8. doi: 10.1186/s12937-015-0026-z

Niazi, S., \& Malik, N. (2013). Self-efficacy as predictor of motivational goals in university students. Journal of the Indian Academy of Applied Psychology, 39, 274-280.

Ogińska-Bulik, N. (2004). Psychology of excessive eating. Łódź: University of Lodz Press.

Rak, E. C. (2014). Employment Outcomes in Persons With Diabetes: The Role of Health Literacy and Diabetes Management Self-Efficacy. Rehabilitation Counseling Bulletin, 57, 159-169. doi: 10.1177/0034355213500816

Rodin, J., Elias, M., Silberstein, L. R., \& Wagner, A. (1988). Combined behavioral and pharmacologic treatment of obesity: Predictors of successful weight maintenance. Journal of Consulting and Clinical Psychology, 56, 399-404. doi: 10.1037/0022006X.56.3.399

Schumacker, R. E., \& Lomax R. G. (2010). A Beginner's Guide to Structural Equation Modeling. New York and London: Taylor and Francis Group, LLC.

Schwarzer, R., \& Renner, B. (2000). Social-cognitive predictors of health behavior: Action self-efficacy and coping self-efficacy. Health Psychology, 19, 487-495. doi: 10.1037/0278-6133.19.5.487

Sijtsma, K. (2009). On the Use, the Misuse, and the Very Limited Usefulness of Cronbach's Alpha. Psychometrika, 74, 107-120. doi: 10.1007/s11336008-9101-0

Stich, C., Knauper, B., \& Tint, A. (2009). A scenario Based Dieting Self-Efficacy Scale. The DIET-SE. Assesment, 16, 16-30. doi: 10.1177/1073191108322000 
Stotland, S., \& Zuroff, D. C. (1991). Relations between multiple measures of dieting self-efficacy and weight change in a behavioral weight control program. Behavior Therapy, 22, 47-59. doi: 10.1016/S0005-7894(05)80243-6

Wiltink, J., Dippel, A., Szczepanski, M., Thiede, R., Alt, C., \& Beutel, M. E. (2007). Long-term weight loss maintenance after inpatient psychotherapy of severely obese patients based on a randomized study: Predictors and maintaining factors of health behavior. Journal of Psychosomatic Research, 62, 691-698. 